DOI: $10.31393 /$ reports-vnmedical-2020-24(3)-04

UDC: $616.34-07-053: 611-018.54$

\title{
IMPORTANCE OF DETERMINATION OF SERUM CHOLINESTERASE LEVEL IN THE DIAGNOSTICS OF INTESTINAL MOTILITY DISORDERS IN CHILDREN
}

\author{
Konoplitskyi V. S., Pogoriliy V. V., Fomin O. O., Lukiyanets O. O., Sasiuk A. I., Dmytriiev D. V., \\ Dmytriiev K. D. \\ National Pirogov Memorial Medical University, Vinnytsya (Pyrogov street 56, Vinnytsya, Ukraine, 21018)
}

Responsible for correspondence: e-mail: vkonoplytsky@gmail.com

Received: June, 19, 2020; Accepted: July, 24, 2020

\begin{abstract}
Annotation. Chronic colostases are characterized by the absence of independent bowel movements due to disturbance of intestinal contractility and evacuatory function of the large intestine which have a negative influence on the development of an organism. The purpose of the study is to evaluate a possibility of predictive diagnostics of motility disorders of the large intestine in children with chronic constipation due to organic causes. The study is based on the determination of serum cholinesterase level in 67 patients of both sexes (main group) which included 25 children suffering from pathology of aganglionic genesis and 42 patients with non-aganglionic congenital anomalies of the large intestine. The average age of the patients was $11.5 \pm 0.8$ years. The control group included children without any pathologies of gastrointestinal tract and central nervous system. The quantitative determination of cholinesterase level was performed by the photometric method described by Molander and Friedman. The group of children suffering from large intestine anomalies of non-aganglionic origin showed an increase in serum cholinesterase level by 1.08 times. The group of children with anomalies of aganglionic origin showed an increase in cholinesterase level by 1.15 times. The increase in cholinesterase level in patients suffering from colostases of non-aganglionic origin can be regarded as a prognostic indicator having the signs of a factor of organic origin. The increase in cholinesterase level in patients suffering from disorders of aganglionic origin shows the presence of neurobiological changes which cannot be solved simply by surgical correction of a congenital anomaly of the intestine. Keywords: cholinesterase, chronic constipation, diagnostics, children.
\end{abstract}

\section{Introduction}

Chronic colostases are diagnosed in $10-25 \%$ of children and in $70 \%$ of gastroenterological patients and are characterized by the absence of independent bowe movements due to disturbance of intestinal contractility and evacuatory function of the large intestine [4]. The frequency of chronic colostases in children younger than age 1 year makes $17.6 \%$ and $10-25 \%$ in the older age, it is registered 3 times more often than in children of preschool age and negatively influences the development of the organism [5].

Modern studies have shown that in the region of neuromuscular junction there are large concentrations of cholinesterase which is able to decompose acetylcholine released from a nerve ending. This fact is very important because normally a muscle receives quick successive nervous impulses and the postsynaptic membrane depolarized by the previous dose of acetylcholine has low sensitivity for the next dose. To ensure that the successive nerve impulses are able to secure a normal excitatory response, it is necessary to remove the previous dose of mediator before each new impulse arrives. This function is performed by cholinesterase due to the fact that choline released from decomposition of acetylcholine is transported back to the nerve ending by a special transport system existing in the presynaptic membrane. Influenced by cholinesterase inhibitors, rhythmic nerve irritation leads to the marked summation of potentials of the terminal plate which results in the stable depolarization of the postsynaptic membrane and blocks the transmission of impulses from nerve fiber to muscle fiber as well as results in the oppression in the adjacent areas of muscle fiber due to inactivation of sodium conductivity and stable increase in the potassium conductivity of the membrane (the state of "cathode depression"). [2]. Certain researchers have proven that patients suffering from chronic colostases are characterized by degenerative changes in the structure of nonstriated muscles of the intestinal wall, and intermuscular plexes are characterized by a decrease in the activity of cholinergic neurons and an abnormal quantity of vasoactive intestinal peptide, nitric oxide, substance $P$, neuropeptide $Y[6,7]$. Nonstriated muscles of the intestinal wall contract due to stimulation of muscarinic acetylcholine receptor which results in the opening of the sodium channels and the efflux of $\mathrm{K}^{+}$ions to the cell. The normalization of $\mathrm{K}^{+}, \mathrm{Na}^{+}$levels leads to the restoration of the membrane polarization and the activation of peristaltic activity of the intestine which is also restored if thiamine is used which leads to a decrease of cholinesterase level [1].

The purpose of the study is to evaluate a possibility of predictive diagnostics of motility disorders of the large intestine in children with chronic constipation due to organic causes.

\section{Materials and methods}

The study is based on the determination of serum cholinesterase level in 67 patients of both genders which were included into the main group and received inpatient treatment at the Pediatric Surgery Clinic of National Pirogov Memorial Medical University, Vinnytsia, due to motility 
disorders of the large intestine in the period from 2014 to 2018. The main group included 25 children with pathology of aganglionic genesis (Hirschsprung's disease) at different stage of treatment and 42 patients suffering from non-aganglionic congenital anomalies of the large intestine at the stage of sub- and decompensation (20 children with dolichosigma and 22 children with dolichocolon). The average age of the patients made $11.5 \pm 0.8$ years. The control group included children without any pathologies of gastrointestinal tract and central nervous system. The quantitative determination of cholinesterase level was performed by the photometric method described by Molander and Friedman, with a wavelength of 500-560 $\mathrm{nm}$. The principle of this method consists in the hydrolyzation of acetylcholine chloride under the influence of cholinesterase with formation of acetic acid and choline. In its turn, the acetic acid changes the $\mathrm{pH}$ of the solution the value of which can be determined by using a respective apparatus indicator [3].

\section{Results. Discussion}

Taking into account the diagnostic capacity of the indicator, in order to perform a prognostic evaluation of the large intestine motility we have determined the level of cholinesterase as a subtype of an enzyme which hydrolyzes serum acetylcholine.

The first stage of the study was to determine cholinesterase level in children suffering from chronic colostases of non-aganglionic genesis due to organic causes.

The data received for both groups is shown in the table 1.

The results of the study in the group of children suffering from congenital anomalies of the large intestine development of non-aganglionic origin showed a reliable increase in serum cholinesterase level by 1.08 times.

The second stage of our study was to determine cholinesterase level in children with chronic motility disorders of the large intestine due to organic causes as well as in children suffering from Hirschsprung's disease at different stages of treatment of this pathology; the respective data are presented in the table 2.

The results of the study in the group of children suffering from congenital anomalies of the large intestine development of aganglionic origin showed a reliable increase in serum cholinesterase level by 1.15 times.

By comparing cholinesterase levels in patients of both main groups it was established that in children suffering from Hirschsprung's disease (at different stages of treatment) its level had higher average values than in patients with dolichosigma and dolichocolon, i.e. $10098.6 \pm 131.3$ and $9467.2 \pm 129.9$ respectively $(p<0.05)$.

Thus, the obtained data confirm the reliable increase in

\section{References}

1. Berezhnyi, V. V., \& Kozachuk, V. H. (2016). Novyi pidkhid u likuvanni ditei rannoho viku z funktsionalnymy rozladamy shlunkovo-kyshkovoho traktu [A new approach in the treatment of young children with functional disorders of the
Table 1. Cholinesterase level in both comparison groups

\begin{tabular}{|c|c|c|c|}
\hline Indicator, $(\mathrm{U} / \mathrm{L})$ & $\begin{array}{c}\text { Control group, } \\
\mathrm{n}=40\end{array}$ & $\begin{array}{c}\text { Main group, } \\
\mathrm{n}=42\end{array}$ & $\mathrm{p}$ \\
\hline $\begin{array}{c}\text { Serum cholinesterase } \\
\text { level }\end{array}$ & $8777.9 \pm 139.2$ & $9467.2 \pm 129.9$ & $<0.05$ \\
\hline
\end{tabular}

Table 2. Cholinesterase level in both comparison groups.

\begin{tabular}{|c|c|c|c|}
\hline Indicator, $(U / L)$ & $\begin{array}{c}\text { Control group, } \\
\mathrm{n}=40\end{array}$ & $\begin{array}{c}\text { Main group, } \\
\mathrm{n}=42\end{array}$ & $\mathrm{p}$ \\
\hline $\begin{array}{c}\text { Serum cholinesterase } \\
\text { level }\end{array}$ & $8777.9 \pm 139.2$ & $10098.6 \pm 131.3$ & $<0.05$ \\
\hline
\end{tabular}

serum cholinesterase level in children suffering from chronic colostases. Besides, it has been established that in children suffering from Hirschsprung's disease (at different stages of treatment) cholinesterase level is significantly higher than in patients with dolichosigma and dolichocolon which confirms the presence of neurobiological changes which cannot be solved by simple surgical correction of a congenital anomaly of the intestine in the form of agangliosis.

Therefore, the dynamics of cholinesterase level can be regarded as a prognostic marker of the motor activity of the large intestine at the stages of treatment of children suffering from chronic colostases.

\section{Conclusions and prospects for further development}

1. The results of study of cholinesterase levels in children suffering from chronic colostases of nonaganglionic genesis showed its increase up to $9467.2 \pm 129.9 \mathrm{U} / \mathrm{L}$ which equals only to $8777.9 \pm 139.2 \mathrm{U} / \mathrm{L}$ $(p<0.05)$ in the control group and can be regarded as a prognostic indicator having the signs of a factor of organic origin.

2. Besides, we have specifically studied the determination of cholinesterase as a biochemical marker of activation ability of the peristaltic activity. The study results showed an average level of cholinesterase in children with chronic motility disorders of the large intestine of aganglionic origin at $10098.6 \pm 131.3 \mathrm{U} / \mathrm{L}$, whereas this indicator in the control group made up to $8777.9 \pm 139.2 \mathrm{U} /$ $L(p<0.05)$, this confirms the presence of neurobiological changes which cannot be solved simply by surgical correction of a congenital anomaly of the intestine in the form of agangliosis in patients suffering from Hirschsprung's disease.

Perspective of the further study is to conduct diagnostic and treatment algorithms for children with constipations if aganglionic and non-aganglionic origin at the background of individual evaluation of the acetylcholinesterase level on the different stages of the process.

gastrointestinal tract]. Sovremennaia pedyatryia - Modern Pediatrics, 8, 116-122. Vziato z http://nbuv.gov.ua/UJRN/ Sped_2016_8_23

2. Erofeev, N. P. (2014). Fiziologiya czentral'noj nervnoj sistemy`: 
uchebnoe posobie [Physiology of the central nervous system: textbook.]. S-Pb.: SpeczLit. ISBN: 978-5-299-00841-8

3. Karpishhenko, A. I. (2012). Mediczinskie laboratorny 'e tekhnologii: rukovodstvo po klinicheskoj laboratornoj diagnostike [Medical laboratory technology: a guide to clinical laboratory diagnosis]. M.: GE' OTAR-Media. ISBN 978-5-97042274-8

4. Kucherov, Yu. I., Zhirkova, Yu. V., Shishkina, T. N., \& Rekhviashvili, M. G. (2015). Poroki razvitiya kishechnika u nedonoshenny 'kh, protekayushhie pod vidom nekroticheskogo e'nterokolita [Intestinal malformations in premature infants, proceeding under the guise of necrotizing enterocolitis]. Voprosy' sovremennoj pediatrii - Questions of modern pediatrics, 14 (2), 300-304. DOI: $10.15690 / v s p . v 14 i 2.1303$

5. Palatnaya, L. A. (2016). Novy’j podkhod v reshenii problemy funkczional'ny`kh gastrointestinal'ny`kh rasstrojstv pishhevareniya u detej pervogo goda zhizni [A new approach to solving the problem of functional gastrointestinal digestive disorders in children of the first year of life]. Pediatriya Pediatrics, 9, 10. Vzyato s http://health-ua.com/wp-content/ uploads/2016/11/2016_Pediatria_3_10.pdf

6. Ding, C., Ge, X., \& Zhang, X., Tian, H., Wang, H., Gu, L., ... \& Li, N. (2016). Efficacy of symbiotic in patients with slow transit constipation: a prospective randomized trial. Nutrients, 8 (10), 1-10. doi: $10.3390 /$ nu8100605

7. Knowles, C. H., \& Farrugia, G. (2011). Gastrointestinal neuromuscular pathology in chronic constipation. Best. Pract. Res. Clin. Gastroenterol., 25 (1), 43-57. doi: 10.1016/ j.bpg.2010.12.001

\section{Список посилань}

1. Бережний, В. В., \& Козачук, В. Г. (2016). Новий підхід у лікуванні дітей раннього віку з функціональними розладами шлунково-кишкового тракту. Современная педиатрия, 8 , 116-122. Взято з http://nbuv.gov.ua/UJRN/Sped_2016_8_23

2. Ерофеев, Н.П. (2014). Физиология иентральной нервной системы: учебное пособие. С-Пб.: СпецЛит. ISBN: 978-5299-00841-8

3. Карпищенко, А. И. (2012). Медицинские лабораторные технологии: руководство по клинической лабораторной диагностике. М.: ГЭОТАР-Медиа. ISBN 978-5-9704-2274-8

4. Кучеров, Ю. И., Жиркова, Ю. В., Шишкина, Т. Н., \& Рехвиашвили, М. Г. (2015). Пороки развития кишечника у недоношенных, протекающие под видом некротического энтероколита. Вопросы современной педиатрии, 14 (2), 300-304. DOI: 10.15690/vsp.v14i2.1303

5. Палатная, Л. А. (2016). Новый подход в решении проблемы функциональных гастроинтестинальных расстройств пищеварения у детей первого года жизни. Педиатрия, 9 , 10. Взято с http://health-ua.com/wp-content/uploads/2016/ 11/2016_Pediatria_3_10.pdf

6. Ding, C., Ge, X., \& Zhang, X., Tian, H., Wang, H., Gu, L., ... \& $\mathrm{Li}, \mathrm{N}$. (2016). Efficacy of symbiotic in patients with slow transit constipation: a prospective randomized trial. Nutrients, 8 (10), 1-10. doi: $10.3390 /$ nu8100605

7. Knowles, C. H., \& Farrugia, G. (2011). Gastrointestina neuromuscular pathology in chronic constipation. Best. Pract. Res. Clin. Gastroenterol., 25 (1), 43-57. doi: 10.1016/ j.bpg.2010.12.001

\section{ЗНАЧЕННЯ ВИЗНАЧЕННЯ РІВНЯ ХОЛІНЕСТЕРАЗИ СИРОВАТКИ КРОВІ В ДІАГНОСТИЦІ ПОРУШЕНЬ КИШКОВОГО ТРАНЗИТУ У ДІТЕЙ}

Конопліцький В. С., Погорілий В. В., Фомін О. О., Лукіянець О. О., Сасюк А. І., Дмитрієв Д. В., Дмитрієв К. Д.

Анотація. Хронічні колостази характеризуються відсутністю самостійних випорожнень через порушення скорочувальної здатності та евакуаторної функції товстої кишки, негативно впливаючи на розвиток організму. Метою дослідження є оцінка можливості прогностичної діагностики порушень товстокишкового транзиту у дітей з хронічними закрепами органічного генезу. Дослідження базується на визначенні рівня холінестерази сироватки крові у 67 хворих обох статей, що становили основну групу, яка включала 25 дітей з патологією агангліонарного ґенезу та 42 пацієнти із неагангліонарними вродженими вадами

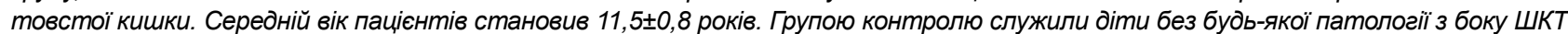
та ЦНС. Кількісне визначення рівня холінестерази проводили фотометричним методом Моландера-Фрідмана. У групі дітей 3 вадами товстої кишки неагангліонарного походження виявлено збільшення рівня холінестерази сироватки крові в 1,08 рази. У групі дітей з вадами агангліонарного походження виявлено збільшення рівня холінестерази сироватки крові в 1,15 рази. Збільшення рівня холінестерази при колостазах неагангліонарного ґенезу може розцінюватись як прогностичний показник, який набуває ознак чинника органічного походження. Збільшення рівня холінестерази при порушеннях агангліонарного походження свідчить про наявність нейробіологічних змін, які не вирішуються суто оперативною корекцією вродженої вади кишки.

Ключові слова: холінестераза, хронічний закреп, діагностика, діти.

\section{ЗНАЧЕНИЕ ОПРЕДЕЛЕНИЯ УРОВНЯ ХОЛИНЭСТЕРАЗЫ СЫВОРОТКИ КРОВИ В ДИАГНОСТИКЕ НАРУШЕНИЙ КИШЕЧНОГО ТРАНЗИТА У ДЕТЕЙ \\ Коноплицкий В. С., Погорелый В. В., Фомин А. А., Лукиянець О. А., Сасюк А. И., Дмитриев Д. В., Дмитриев К. Д.} Аннотация. Хронические колостазы характеризуются отсутствием самостоятельного стула из-за нарушения сократительной способности и эвакуаторной функции толстой кишки, негативно влияя на развитие организма. Целью исследования является оценка возможности прогностической диагностики нарушений толстокишечного транзита у детей с хроническими запорами органического генеза. Исследование базируется на определении уровня холинэстеразы сыворотки крови у 67 больных обоего пола, которые составили основную группу, которая включала 25 детей с патологией аганглионарного генеза и 42 пациента с неаганглионарными врожденными пороками толстой кишки. Средний возраст пациентов составил $11,5 \pm 0,8$ лет. Группой контроля служили дети без каких-либо патологий со стороны ЖКТ и ЦНС. Количественное определение уровня холинэстеразы проводили фоотометрическим методом Моландера-Фридмана. В группе детей с пороками толстой кишки неаганглионарного происхождения обнаружено увеличение уровня холинэстеразы сыворотки крови в 1,08 раза. В группе детей с пороками аганглионарного происхождения обнаружено увеличение уровня холинэстеразы сыворотки крови в 1,15 раза. Увеличение уровня холинэстеразы при колостазах неаганглионарного генеза может расцениваться как прогностический показатель, который приобретает признаки фрактора органического происхождения. Увеличение уровня холинэстеразы при нарушениях аганглионарного происхождения свидетельствует о наличии нейробиологических изменений, которые не решаются сугубо оперативной коррекцией врожденного порока кишки.

Ключевые слова: холинэстераза, хронический запор, диагностика, дети. 